\title{
The Ehrlich Tumor Induces Pain-Like Behavior in Mice: A Novel Model of Cancer Pain for Pathophysiological Studies and Pharmacological Screening
}

\author{
Cassia Calixto-Campos, ${ }^{1}$ Ana C. Zarpelon, ${ }^{1}$ Mab Corrêa, ${ }^{1}$ Renato D. R. Cardoso, ${ }^{1}$ \\ Felipe A. Pinho-Ribeiro, ${ }^{1}$ Rubens Cecchini, ${ }^{1}$ Estefania G. Moreira, ${ }^{2}$ Jefferson Crespigio, \\ Catia C. F. Bernardy, ${ }^{3}$ Rubia Casagrande, ${ }^{4}$ and Waldiceu A. Verri Jr. ${ }^{1}$ \\ ${ }^{1}$ Departamento de Ciências Patológicas, Centro de Ciências Biológicas, Universidade Estadual de Londrina, \\ Rod. Celso Garcia Cid KM480 PR445, 86051-990 Londrina, PR, Brazil \\ ${ }^{2}$ Departamento de Ciências Fisiológicas, Centro de Ciências Biológicas, Universidade Estadual de Londrina, \\ Rod. Celso Garcia Cid KM480 PR445, 86051-990 Londrina, PR, Brazil \\ ${ }^{3}$ Departamento de Enfermagem, Centro de Ciências da Saúde, Universidade Estadual de Londrina, \\ Avenida Robert Koch 60, 86038-350 Londrina, PR, Brazil \\ ${ }^{4}$ Departamento Ciências Farmacêuticas, Centro de Ciências da Saúde, Universidade Estadual de Londrina, \\ Avenida Robert Koch 60, 86038-350 Londrina, PR, Brazil \\ Correspondence should be addressed to Waldiceu A. Verri Jr.; waldiceujr@yahoo.com.br
}

Received 29 April 2013; Accepted 10 July 2013

Academic Editor: Monica Fedele

Copyright (C) 2013 Cassia Calixto-Campos et al. This is an open access article distributed under the Creative Commons Attribution License, which permits unrestricted use, distribution, and reproduction in any medium, provided the original work is properly cited.

\begin{abstract}
The Ehrlich tumor is a mammary adenocarcinoma of mice that can be developed in solid and ascitic forms depending on its administration in tissues or cavities, respectively. The present study investigates whether the subcutaneous plantar administration of the Ehrlich tumor cells induces pain-like behavior and initial pharmacological susceptibility characteristics. The Ehrlich tumor cells $\left(1 \times 10^{4}-10^{7}\right.$ cells) induced dose-dependent mechanical hyperalgesia (electronic version of the von Frey filaments), paw edema/tumor growth (caliper), and flinches compared with the saline group between days 2 and 12 . There was no difference between doses of cells regarding thermal hyperalgesia in the hot-plate test. Indomethacin (a cyclooxygenase inhibitor) and amitriptyline hydrochloride (a tricyclic antidepressant) treatments did not affect flinches or thermal and mechanical hyperalgesia. On the other hand, morphine (an opioid) inhibited the flinch behavior and the thermal and mechanical hyperalgesia. These effects of morphine on pain-like behavior were prevented by naloxone (an opioid receptor antagonist) treatment. None of the treatments affected paw edema/tumor growth. The results showed that, in addition to tumor growth, administration of the Ehrlich tumor cells may represent a novel model for the study of cancer pain, specially the pain that is susceptible to treatment with opioids, but not to cyclooxygenase inhibitor or to tricyclic antidepressant.
\end{abstract}

\section{Introduction}

Pain is a symptom related to poor quality of life in cancer patients. In fact, in the United States, it is the most frequent cause of disability in these patients $[1,2]$. Furthermore, reports of cancer pain have been increasing over the years accompanying the increased survival of patients $[3,4]$. Most patients with advanced cancer $(60 \%-85 \%)$ and 5-year survivors (40\%) report pain [5-8]. In patients with advanced cancer, $62 \%-85 \%$ experience significant pain that is described as moderate to severe in approximately $4 \%-50 \%$ and as very severe in $25 \%-30 \%$ [9]. In fact, approximately $43 \%$ of the patients report feeling pain as early as diagnosis [7]. Therefore, pain management in cancer patients is a public health issue, and the mechanisms of cancer pain are not completely understood [7].

In this sense, there are various animal models of cancer pain that are used in an attempt to clarify the nociceptive 
pathways involved in cancer-related pain, including skin cancer pain [10], neuropathic cancer pain [11], and bone cancer pain $[12,13]$. These models have been important, for instance, in the demonstration of the contribution of transient receptor potential vanilloid receptor 1 (TRPV1), acidsensing ion channels (ASICs), nerve growth factor (NGF), bradykinin, adenosine triphosphate (ATP), endothelin, and other mediators in the nociceptor sensitization during cancer pain [14]. There is also evidence that the inflammatory response against the tumor cells results in the production of cytokines and chemokines that sensitize the nociceptors by receptor-mediated activation of protein kinase $\mathrm{C}$ (PKC) and protein kinase A (PKA) and/or activation of mytogenactivated protein kinases such as p38. The activation of these intracellular pathways results in activation of TRPV1 and tetrodotoxin-resistant sodium channels and increased expression of TRPV1 [15]. Therefore, there are complex mechanisms, which may also vary depending on the cancer type.

The Ehrlich tumor is a spontaneous murine mammary adenocarcinoma [16] adapted to ascites form [17] and carried in mice by serial intraperitoneal (i.p.) passages [18]. The ascitic form of the tumor has been used as experimental model to assess the influence of drugs of different origins on its proliferation and host responses against the tumor cells [19-21]. The characteristic ascites is probably formed as a consequence of the inflammatory response towards tumor cells resulting in increased peritoneal vascular permeability [22]. Other factors that contribute to ascites and lethality of the Ehrlich tumor includes the impaired peritoneal lymphatic drainage by the tumor cells [22], the mechanic pressure exerted by progressive increase of ascitic fluid, peritoneal hemorrhage, and endotoxemia [23-25]. The Ehrlich tumor cells are also used as a model of solid tumor by injection in different sites [26].

Despite the wide use of the Ehrlich tumor cells in the investigation of the mechanisms of tumor proliferation as well as the host inflammatory and oxidative responses against tumor cells, it is yet undetermined whether inoculation of the Ehrlich tumor cells could represent a murine model to study cancer pain. Therefore, the present study standardized a murine model of cancer pain induced by the intraplantar injection of the Ehrlich tumor cells and investigated the pharmacological susceptibility of the model using three classes of analgesics.

\section{Materials and Methods}

2.1. Animals. The experiments were performed on male Swiss mice (20-25 g, Universidade Estadual de Londrina, Londrina, PR, Brazil) housed in standard clear plastic cages (six per cage) with free access to food and water. The behavioral testing was performed between 9:00 am and 5:00 pm in a temperature-controlled room. Animals' care and handling procedures were in accordance with the International Association for Study of Pain (IASP) guidelines and with the approval of the Ethics Committee of Universidade Estadual de Londrina. All efforts were made to minimize the number of animals used and their suffering.
2.2. The Ehrlich Tumor Cells Inoculation. The Ehrlich tumor cells were collected from ascitic fluid of the peritoneal cavity of mice 10 days after tumor administration. The ascitic fluid was washed in phosphate-buffered saline (PBS, $\mathrm{pH}$ 7.4), centrifuged (200 g, $10 \mathrm{~min}$ ), and washed with PBS three times. The cell viability was determined by the $0.5 \%$ trypan blue exclusion method in the Neubauer chamber [27]. The Ehrlich tumor cells were suspended to the final concentrations of $1 \times 10^{4}, 1 \times 10^{5}, 1 \times 10^{6}$, and $1 \times 10^{7}$ in $25 \mu \mathrm{L}$ of saline. Measurements were performed before and after injection of tumor cells between days 0 and 12 .

2.3. Drugs. Drugs were obtained from the following sources: indomethacin from Prodome Chemical and Pharmaceutical (Sao Paulo, SP, Brazil), amitriptyline from Germed (Sao Bernardo do Campo, SP, Brazil), morphine sulphate from Cristalia (São Paulo, SP, Brazil), and naloxone hydrochloride from Sigma-Aldrich (St Louis, MO, USA).

2.4. Protocols. Firstly, mice received intraplantar (i.pl.) injection of the Ehrlich tumor cells $\left(1 \times 10^{4}-10^{7}\right.$ in $\left.25 \mu \mathrm{L}\right)$ or saline. Measurements of mechanical and thermal hyperalgesia, paw edema/tumor growth, and overt pain-like behavior were performed on days $0-12$. According to the results, the dose of $1 \times 10^{6} /$ paw of tumor cells was chosen for next experiments of mechanical hyperalgesia, thermal hyperalgesia, paw edema/tumor growth, and histological analysis at indicated timepoints. The dose of $1 \times 10^{7} / \mathrm{paw}$ of tumor cells and evaluation at the 8th day after inoculation were chosen for experiments of overt pain. Paw samples were collected for histological analysis and microscopic observation 12 days after tumor injection. To evaluate the hyperalgesic effect of cellular remnants, the Ehrlich tumor cells were inactivated and injected i.pl., and compared with the saline and the viable Ehrlich tumor cells groups; measurements were performed on days $0-12$. To evaluate the pharmacological modulation of the Ehrlich tumor-induced pain-like behavior, mice were treated with the cyclooxygenase inhibitor (indomethacin, $0.7,2$, and $6 \mathrm{mg} / \mathrm{kg}$, i.p.) or opioid (morphine, 1, 3, and $10 \mathrm{mg} / \mathrm{kg}$, i.p.) on the 8th day after the Ehrlich tumor cells administration, and the evaluation of mechanical and thermal hyperalgesia, paw edema/tumor growth, and overt pain was performed $3 \mathrm{~h}$ or $45 \mathrm{~min}$ after the treatment, respectively. Another group of mice was treated with tricyclic antidepressant (amitriptyline, 3,10 , and $30 \mathrm{mg} / \mathrm{kg}$, p.o.) daily during 12 days. The evaluation of mechanical and thermal hyperalgesia, paw edema/tumor growth, and overt pain was performed $3 \mathrm{~h}$ after treatment on days $0-12$. It is noteworthy that different experimenters prepared the solutions, made the administrations, and performed the evaluation of pain-like behavior.

2.5. The Electronic Pressure Meter Test of Mechanical Hyperalgesia. Mechanical hyperalgesia was tested in mice as previously reported [28]. Briefly, the test consists of evoking a hindpaw flexion reflex with a hand-held force transducer (the electronic von Frey anesthesiometer: Insight, Ribeirão Preto, SP, Brazil) adapted with a $0.5 \mathrm{~mm}^{2}$ contact area polypropylene tip. The investigator was trained to apply the tip perpendicularly to the central area of the hindpaw, and the endpoint 
was characterized by the removal of the paw. The results are expressed by delta $(\Delta)$ withdrawal threshold (in $g$ ), which was calculated by subtracting the zero-time mean measurements from the mean measurements (indicated timepoints) after stimulus.

2.6. The Hot-Plate Test of Thermal Hyperalgesia. Thermal hyperalgesia was evaluated before and at indicated timepoints after injection of the Ehrlich tumor cells. In brief, mice were placed in a $10 \mathrm{~cm}$ wide glass cylinder on a hot plate (Hot Plate HP-2002, Insight Equipamentos, Ribeirao Preto, SP, Brazil) maintained at $55^{\circ} \mathrm{C}$. The reaction time was scored when the animal jumped, flinched, and/or licked its paws. A maximum latency (cutoff) was set at $30 \mathrm{~s}$ to avoid tissue damage [29].

2.7. Evaluation of Paw Edema/Tumor Growth. The paw edema/tumor growth was determined before and at indicated timepoints (at $48 \mathrm{~h}$ intervals) after the injection of the Ehrlich tumor cells using an analog caliper. Paw edema/tumor growth was presented as $\Delta \mathrm{mm}[29]$.

2.8. Overt Pain-Like Behavior Evaluation. Mice were placed in clear glass compartments at room temperature. After an acclimation period of $15 \mathrm{~min}$, mice were observed for $10 \mathrm{~min}$, and the cumulative number of flinches was measured [27].

2.9. Histopathological Analysis. On the 12th day after injection of tumor cells, mice were killed, and the paws were removed and fixed in the Bowen solution (75\% picric acid, $25 \%$ formaldehyde, and 5\% acetic acid) for 21 days. The samples were embedded in paraffin, sectioned into $5 \mu \mathrm{m}$ sections, and stained with hematoxylin and eosin for light microscopic observation.

2.10. Inactivation of the Ehrlich Tumor Cells by Thermal Alteration. The Ehrlich tumor cells were inactivated to evaluate the involvement of cellular remnants in pain induced by the Ehrlich tumor cells. For this, the cells were inactivated by the process of freezing and heating. The Ehrlich tumor cells were first suspended to the final concentration of $1 \times 10^{6}$ or $1 \times$ $10^{7}$; next cell suspension was submerged in liquid nitrogen for $5 \mathrm{~min}$ and then heated in water-bath $\left(80^{\circ} \mathrm{C}\right)$ during $5 \mathrm{~min}$ (EvLab, Londrina, PR, Brazil). This process was repeated 5 times, followed by assessment of cell viability by the trypan blue test, in order to confirm that cells were not viable. Mice received the equivalent to $1 \times 10^{6}$ or $1 \times 10^{7}$ inactivated tumor cells, viable cells, or saline $(25 \mu \mathrm{L})$ i.pl. The evaluation of mechanical and thermal hyperalgesia and paw edema/tumor growth was performed between days 0 and 12 and, the evaluation of the overt pain was performed in 8th day.

2.11. Statistical Analysis. Results are presented as mean \pm SEM of measurements made on 6 animals in each group in each experiment and are representative of two independent experiments. The two-way analysis of variance (ANOVA) was used to compare the groups and doses at all times (curves) when the hyperalgesic responses were measured at different times after the stimulus injection. The analyzed factors were treatment, time, and time versus treatment interaction. When there was a significant time versus treatment interaction, one-way ANOVA followed by Tukey's $t$-test was performed for each time. On the other hand, when the hyperalgesic responses were measured once after the stimulus injection, the differences between responses were evaluated by one-way ANOVA followed by Tukey's $t$-test. Additionally, comparative statistical analysis between two groups was done using the $t$ test. Statistical differences were considered to be significant at $P<0.05$.

\section{Results}

3.1. The Subcutaneous Injection of the Ehrlich Cells Induces Mechanical and Thermal Hyperalgesia, Paw Edema/Tumor Growth, and Overt Pain-Like Behavior in a Dose-Dependent Manner. The Ehrlich tumor cells $\left(1 \times 10^{4}-10^{7}\right.$ in $25 \mu \mathrm{L}$ per paw), or the vehicle group (PBS), were subcutaneously injected in the mouse hindpaw (i.pl.), and mechanical hyperalgesia was evaluated 2, 4, 6, 8, 10, and 12 days after cell injection, Figure 1(a). The mechanical hyperalgesia induced by tumor cells was dose and time dependent. All doses of tumor cells tested induced significant mechanical hyperalgesia on day 8 , which remained on days 10 and 12 . There was no statistical difference between the doses of $10^{6}$ and $10^{7}$ tumor cells regarding mechanical hyperalgesia, Figure 1(a). There was no difference between the doses in the hot-plate test (data not shown); therefore, for clear presentation, only the results on thermal hyperalgesia and the dose of $10^{6}$ are shown in Figure 1(b). The injection of tumor cells induced a progressive and dose-dependent increase in paw edema/tumor growth, Figure 1(c), which corroborates the progressive increase of mechanical hyperalgesia in Figure 1(a). The dose of $10^{4}$ did not induce significant paw edema/tumor growth, while $10^{5}$ induced at days 10 and 12, Figure 1(c). The paw edema/tumor growth was significant between 2 and 12 days for the doses of $10^{6}$ and $10^{7}$ (Figure $1(\mathrm{c})$ ). Spontaneous nociceptive behavior was quantified by the number of flinches, Figure $1(\mathrm{~d})$. The doses of $10^{4}$ and $10^{5}$ did not induce paw flinch, the dose of $10^{6}$ induced paw flinch at days $10-12$, and $10^{7}$ induced a significant number of flinches at days $4-12$ with a peak at day 8 (Figure $1(\mathrm{~d})$ ). Considering these results, the dose of the $10^{6}$ Ehrlich tumor cells was chosen for histological analysis and behavioral experiments evaluating mechanical and thermal hyperalgesia and paw edema/tumor growth, while the dose of $10^{7}$ was chosen for overt pain-like behavior evaluation.

3.2. Histopathological Analysis. Mice were sacrificed at day 12 after injection of the Ehrlich tumor cells or saline $(25 \mu \mathrm{L})$, and the paws were collected for histological analysis performed with hematoxylin/eosin staining (Figure 2). There was no histological abnormality in mice that received i.pl. injection of saline (Figure 2(a)), presenting normal epithelium (arrow 1) and normal bone cartilage (arrow 2). Mice that received i.pl. injection of the Ehrlich tumor cells $\left(10^{4}-10^{7}\right)$ showed malignant neoplasm and poor differentiation, characterized by the presence of tumor cells, with nucleus showing frequent aberrant mitosis. Considering that there was no difference between the different doses of tumor cells 


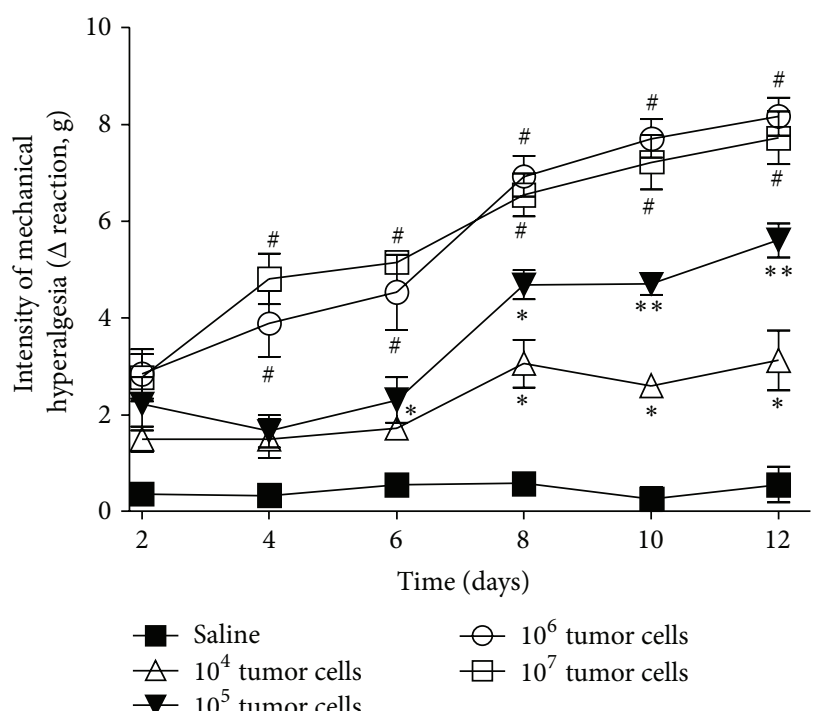

(a)

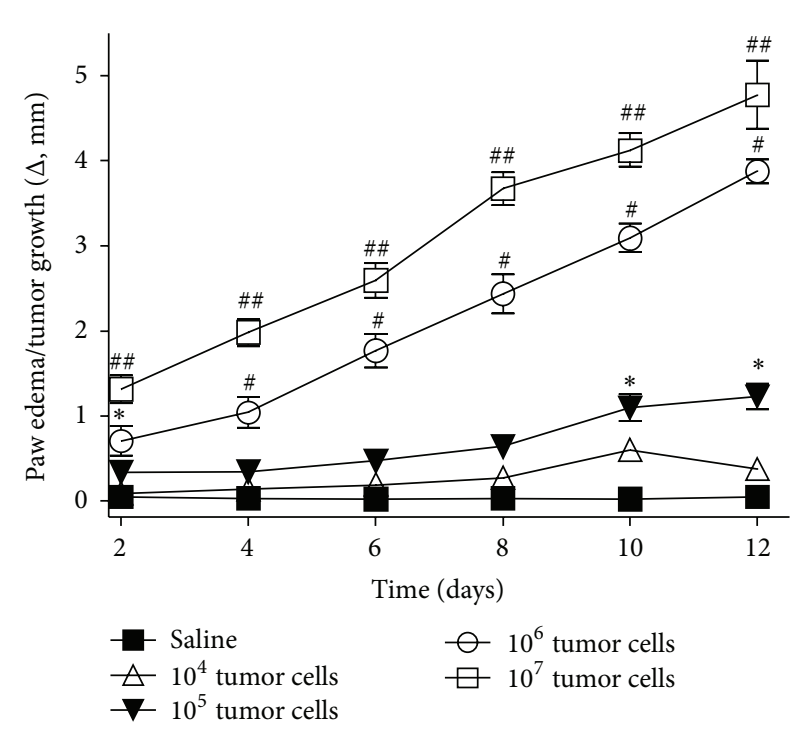

(c)

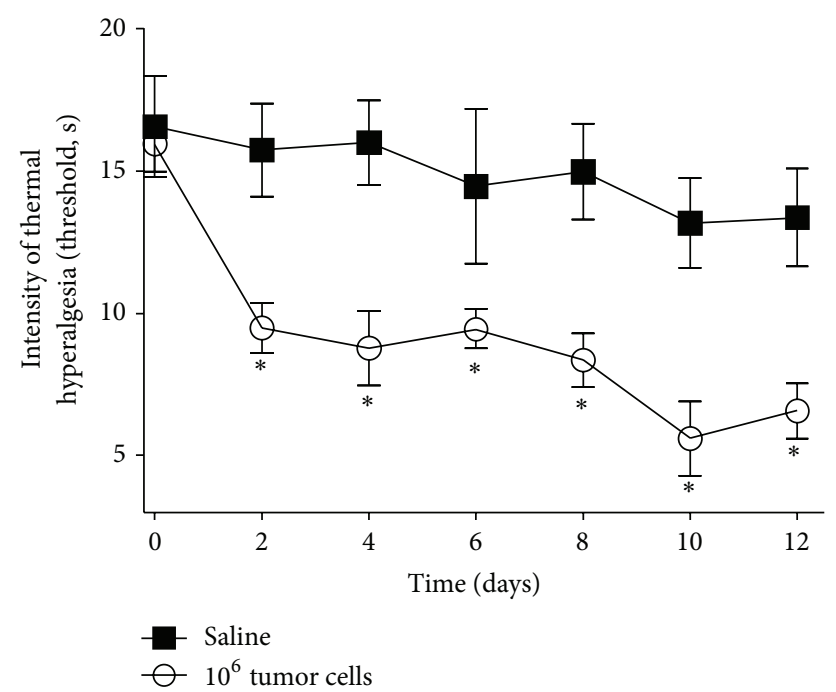

(b)

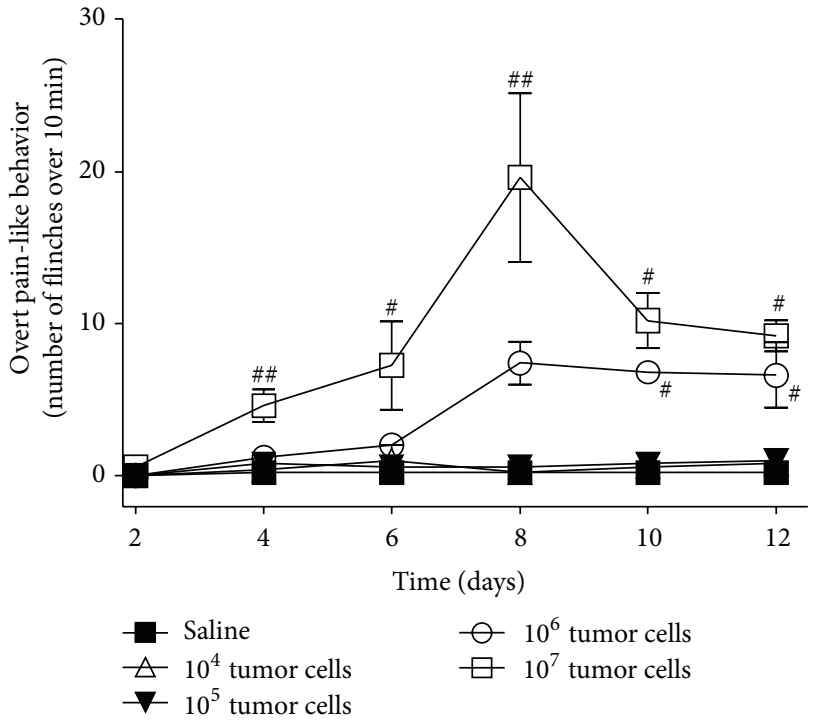

(d)

FIgURE 1: The Ehrlich tumor induces pain and paw edema/tumor growth in a dose-dependent manner. The Ehrlich tumor cells $\left(1 \times 10^{4-7}\right)$ or saline $(25 \mu \mathrm{L})$ was injected subcutaneously in the paw. (a) The intensity of mechanical hyperalgesia, (b) thermal hyperalgesia, (c) paw edema/tumor growth, and (d) overt pain-like behavior was evaluated between 0 and 12 days at every-other-day intervals after injection of tumor cells or saline; $n=6$, representative of two experiments. ${ }^{*} P<0.05$ compared with saline; ${ }^{* *} P<0.05$ compared with saline and the dose of $10^{4} ;{ }^{\#} P<0.05$ compared with saline and the doses of $10^{4}$ and $10^{5} ;{ }^{\#} P<0.05$ compared with saline and the doses of $1 \times 10^{4-6}$.

regarding the tumor characteristics, the figures represent the dose of the $10^{6}$ Ehrlich tumor cells that was used in most of the evaluations (Figures 2(b)-2(h)). Figure 2(b) shows bone cartilage destruction induced by tumor cells (arrow 4). Figure 2(c) shows at $4 \mathrm{x}$ magnification the epithelium (arrow 1) and the presence of tumor cells (arrow 3 ) with intense areas of necrosis (arrow 5). Figure 2(d) shows areas of necrosis (arrow 5) induced by the Ehrlich tumor cells. Figure 2(e) shows at 10x magnification the presence of tumor cells (arrow 3) in a paw tissue, and Figure 2(f) shows tumor cells (arrow 3), areas of necrosis (arrow 5), and a presence of mitosis (arrow 6 ). Figure $2(\mathrm{~g})$ shows the presence of atypical mitosis (arrow
6), and Figure 2(h) shows at 40x magnification mitosis (arrow 6) and tumor cells with atypical nucleus (arrow 7). Therefore, the histopathological analysis confirmed the presence of the tumor cells (Figures 2(b) and 2(h)), together with an extensive area of necrosis (Figures 2(c), 2(d), and 2(f)) characterized by neutrophilic infiltration, associated with the presence of fibrin and red blood cells, which gives an eosinophilic coloration (Figure 2(d)), tumor cells with aberrant mitosis (Figure 2(g)), and bone/cartilage destruction (Figure 2(b)).

3.3. Inactivation of the Ehrlich Tumor Cells by Thermal Alteration Abolishes the Nociceptive Responses. Mice received i.pl. 


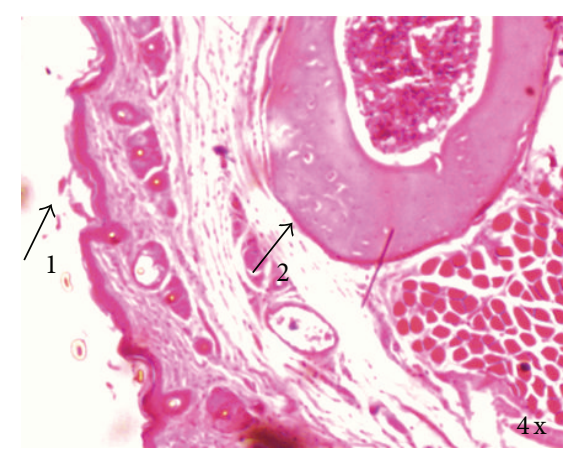

(a)

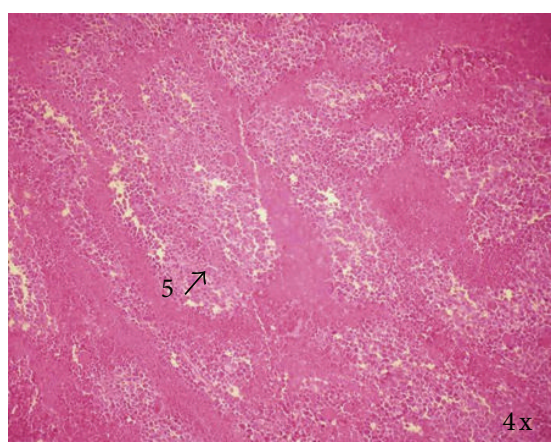

(d)

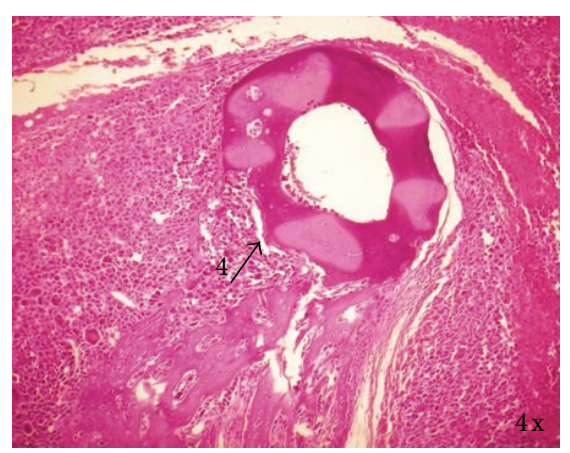

(b)

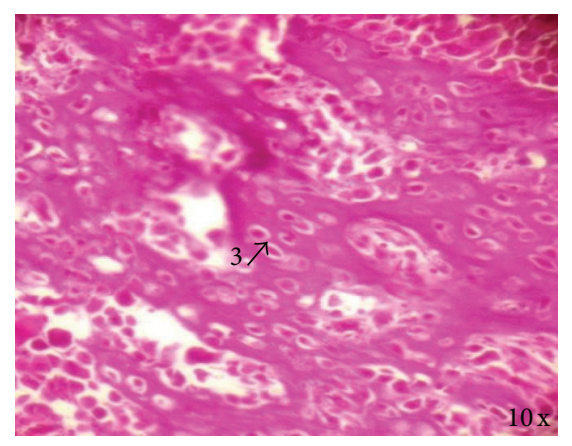

(e)

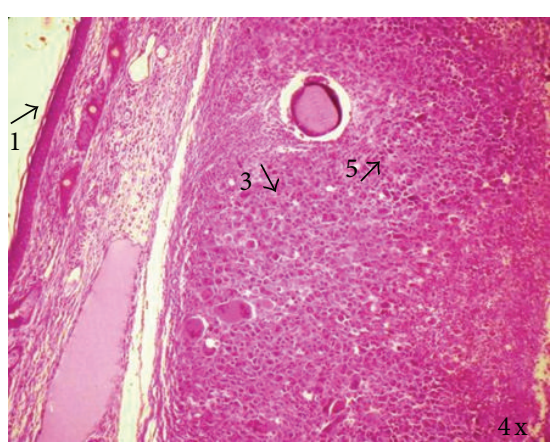

(c)

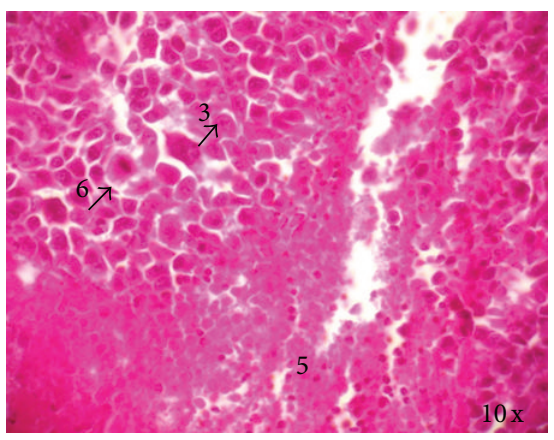

(f)

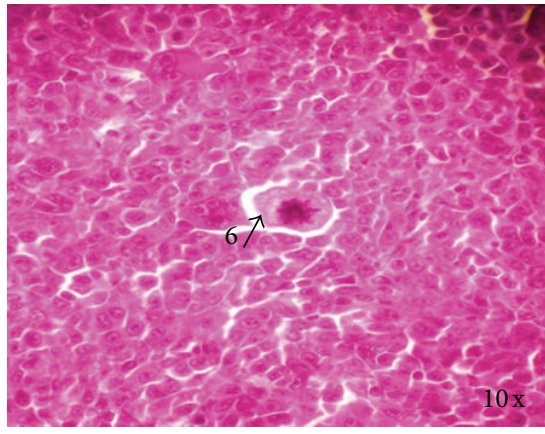

(g)

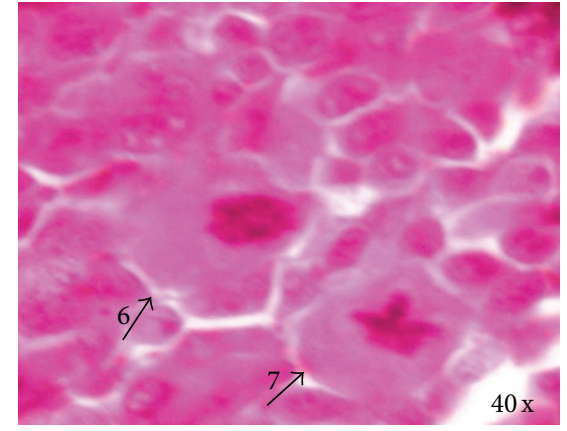

(h)

FIGURE 2: Histopathological analysis of paw injected with the Ehrlich tumor. The Ehrlich tumor cells $\left(1 \times 10^{6}\right)$ or saline $(25 \mu \mathrm{L})$ was injected subcutaneously into the hindpaws of the mice. Panel (a) indicates histological sections of normal paw that received saline, and panels (b)-(h) indicate the paw that received the Ehrlich tumor cells stained by hematoxylin/eosin. Arrows (1) indicate normal epithelium; (2) normal bone cartilage; (3) tumor cells; (4) destroyed bone cartilage; (5) extensive area of necrosis; (6) tumor cells with mitosis or atypical mitosis; (7) and tumor cells with atypical nucleus.

injection of saline $(25 \mu \mathrm{L})$, the viable Ehrlich tumor cells $\left(10^{6}\right.$ or $10^{7} / \mathrm{paw}$ ), or the inactivated Ehrlich tumor cells (equivalent to $10^{6}$ or $10^{7}$ cells). Mechanical and thermal hyperalgesia and paw edema/tumor growth were evaluated between 0 and 12 days, and overt pain-like behavior was evaluated on day 8 after stimulus. The inactivation of the $10^{6}$ Ehrlich tumor cells was able to abolish the mechanical (Figure 3(a)) and thermal (Figure 3(b)) hyperalgesia and paw edema/tumor growth (Figure 3(c)) compared with the viable cells. Inactivation of the $10^{7}$ tumor cells also resulted in abolishment of overt pain-like behavior (Figure 3(d)) compared with the viable cells. Thus, the cellular remnants of the Ehrlich tumor cells were not capable of inducing paw edema/tumor growth and nociceptive responses, which suggests that these responses depend on the proliferation of tumor cells and their activities and interactions with the host immune responses.

\subsection{Effect of Indomethacin Treatment on the Nociceptive} Responses and Paw Edema/Tumor Growth Induced by the Ehrlich Tumor Cells. Mice received the $10^{6}$ or $10^{7}$ Ehrlich tumor cells, and on the 8th day, they were treated with indomethacin $(0.7,2$, or $6 \mathrm{mg} / \mathrm{Kg}$ i.p.) or Tris buffer, and $3 \mathrm{~h}$ after the treatment mechanical, and thermal hyperalgesia, paw edema/tumor growth, and overt pain-like behavior were measured (Figure 4). The Ehrlich tumor cells induced significant mechanical (Figure 4(a)) and thermal (Figure 4(b)) hyperalgesia, paw edema/tumor growth (Figure 4(c)), and overt pain-like behavior (Figure 4(d)) compared with the 


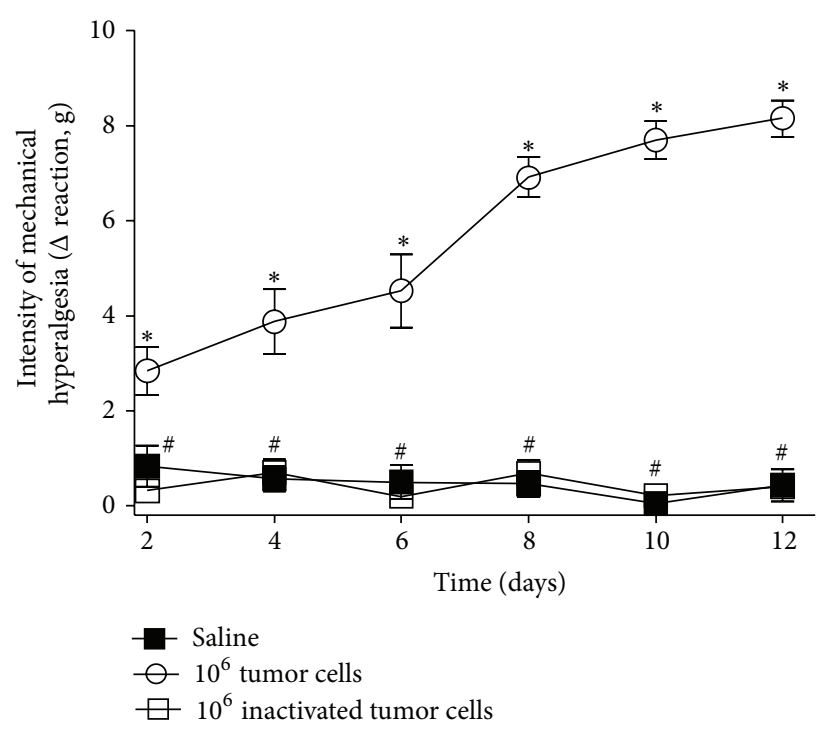

(a)

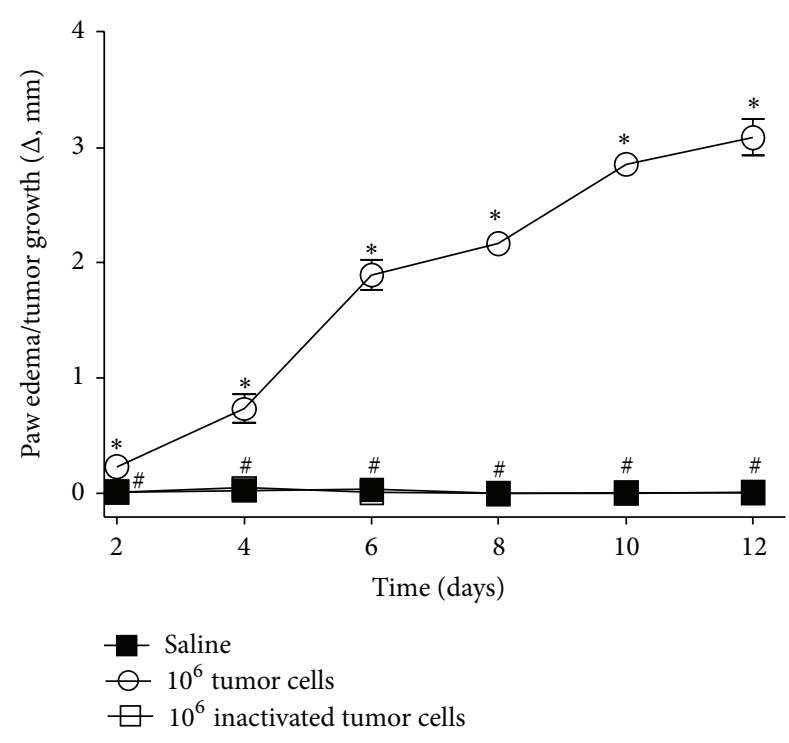

(c)

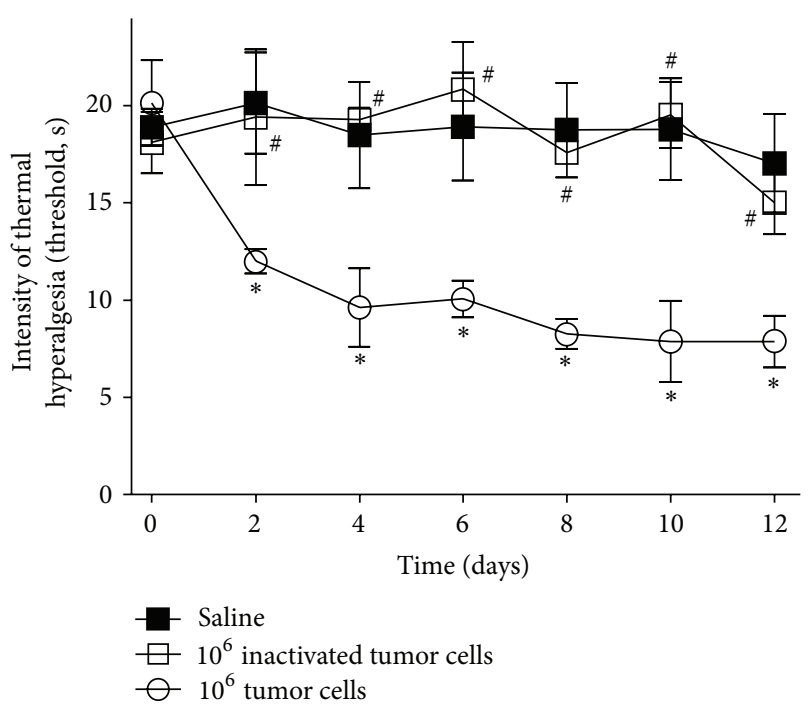

(b)

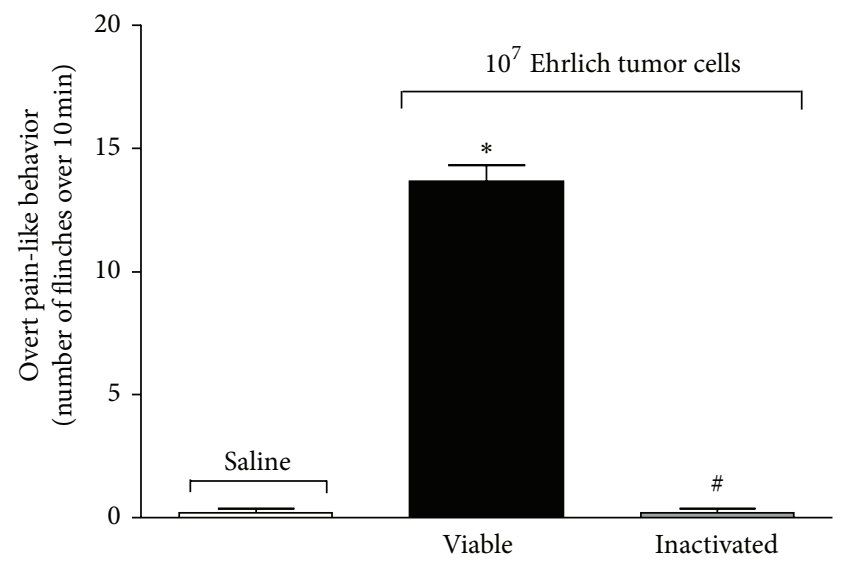

(d)

FIgURE 3: Thermal inactivation of the Ehrlich tumor cells abolishes pain and paw edema/tumor growth. The Ehrlich tumor cells $\left(1 \times 10^{6}\right)$ were inactivated by cold followed by heat. Mice received $25 \mu \mathrm{L}$ of inactivated tumor cells, viable tumor cells $\left(1 \times 10^{6}\right)$, or saline. (a) The intensity of mechanical hyperalgesia, (b) thermal hyperalgesia, and (c) paw edema/tumor growth was evaluated on days 2-12 after injection of the inactivated Ehrlich tumor cells, viable tumor cells, or saline. Mice received $1 \times 10^{7}$ of inactivated tumor cells, viable cells, or saline and (d) the overt pain was evaluated on the 8th day after injection; $n=6$, representative of two experiments. ${ }^{*} P<0.05$ compared with the saline, and ${ }^{\#} P<0.05$ compared with the viable $1 \times 10^{6}$ or $1 \times 10^{7}$ tumor cells.

saline group. However, the treatment with indomethacin did not affect those parameters induced by the Ehrlich tumor cells (Figure 4), indicating that they do not depend on the production of prostanoids.

3.5. Effect of Amitriptyline Treatment on the Nociceptive Responses and Paw Edema/Tumor Growth Induced by the Ehrlich Tumor Cells. After inoculation of the $10^{6}$ or $10^{7}$ Ehrlich tumor cells, mice were treated with amitriptyline (3, 10 , and $30 \mathrm{mg} / \mathrm{kg}$ ) or water via oral gavage (per oral: p.o.) once a day during 12 days, and $3 \mathrm{~h}$ after treatment, mechanical and thermal hyperalgesia, paw edema/tumor growth, and overt pain-like behavior were evaluated (Figure 5). None of the doses of amitriptyline affected the Ehrlich tumor cells-induced mechanical hyperalgesia (Figure 5(a)), thermal hyperalgesia (Figure 5(b)), paw edema/tumor growth (Figure 5(c)), or overt pain (Figure 5(d)). These results suggest that the inhibition of serotonin and/or norepinephrine reuptake does not affect the maintenance of cancer pain in this model. 


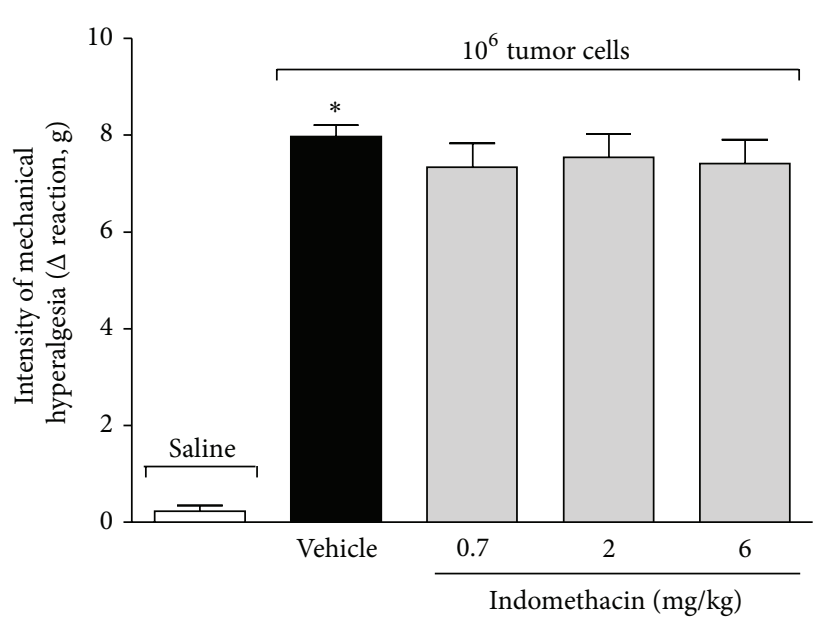

(a)

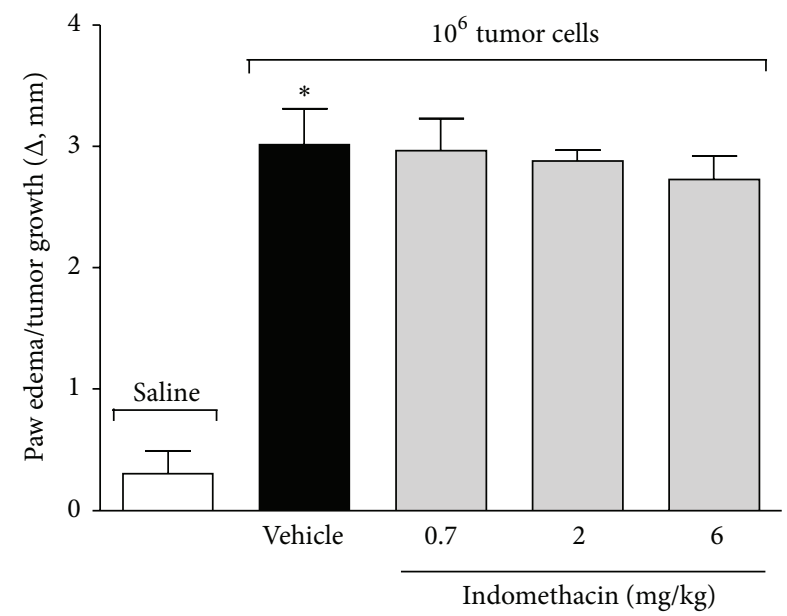

(c)

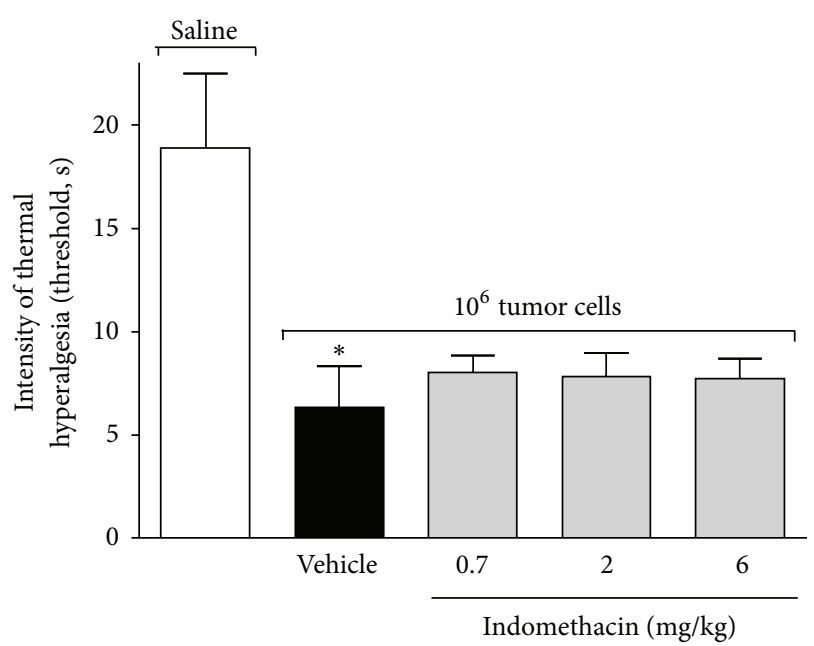

(b)

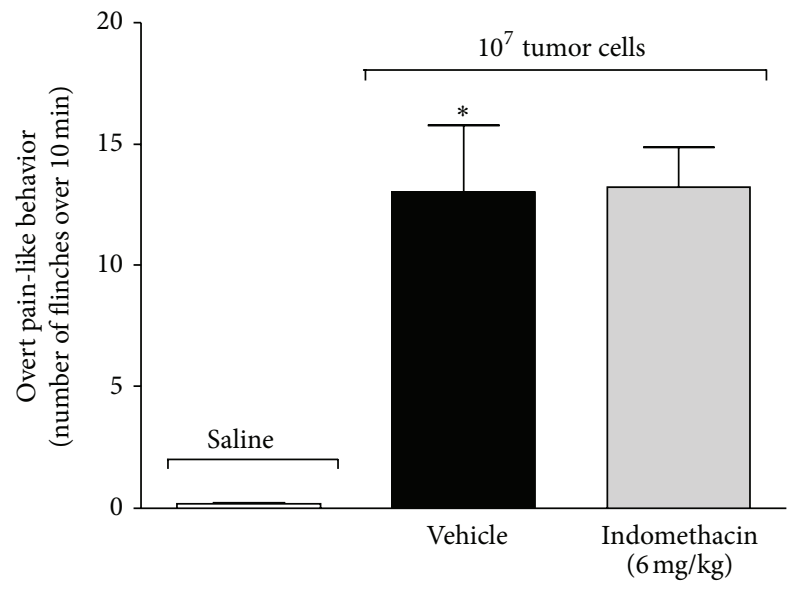

(d)

FIGURE 4: Effect of indomethacin treatment on pain and paw edema/tumor growth induced by the Ehrlich tumor cells. Mice received the $1 \times$ $10^{6}$ Ehrlich tumor cells or saline, and on the 8th day, they were treated with indomethacin $(0.7-6 \mathrm{mg} / \mathrm{kg}$, i.p.) or Tris buffer. (a) The intensity of mechanical hyperalgesia, (b) thermal hyperalgesia, and (c) paw edema/tumor growth was evaluated $3 \mathrm{~h}$ after the treatment. Mice received the $1 \times 10^{7}$ Ehrlich tumor cells or saline, and on 8th day, they were treated with indomethacin $(6 \mathrm{mg} / \mathrm{kg}$ i.p.) or Tris buffer, and (d) overt pain was assessed $3 \mathrm{~h}$ after treatment; $n=6$, representative of two experiments. ${ }^{*} P<0.05$ vehicle group compared with the saline.

3.6. Effect of Morphine Treatment on the Nociceptive Responses and Paw Edema/Tumor Growth Induced by the Ehrlich Tumor Cells. Mice were treated with morphine $(1-10 \mathrm{mg} / \mathrm{kg}$, i.p.) or saline on the 8 th day after the Ehrlich tumor $\left(10^{6}\right.$ or $10^{7}$ cells) injection in which the peak of hyperalgesia was detected. After the treatment ( $45 \mathrm{~min})$ with morphine, mechanical (Figure 6(a)) and thermal (Figure 6(b)) hyperalgesia and paw edema/tumor growth (Figure 6(c)) were evaluated. The morphine dose dependently inhibited Ehrlich tumor-induced mechanical (Figure 6(a)) and thermal (Figure 6(b)) hyperalgesia, but it did not affect the paw edema/tumor growth, which indicates that morphine presents analgesic effect not related to inhibition of tumor proliferation. The dose of $3 \mathrm{mg} / \mathrm{kg}$ of morphine reduced the Ehrlich tumor-induced mechanical hyperalgesia compared with the positive control, while the dose of $10 \mathrm{mg} / \mathrm{kg}$ of morphine presented significant inhibition compared with the Ehrlich tumor-positive control and the doses of 1 and $3 \mathrm{mg} / \mathrm{kg}$ of morphine (Figure 6(a)). The Ehrlich tumor-induced thermal hyperalgesia was inhibited by the dose of $10 \mathrm{mg} / \mathrm{kg}$ of morphine without significant inhibition with the doses of 1 and $3 \mathrm{mg} / \mathrm{kg}$ (Figure 6(b)). To confirm the receptor-dependent effect of morphine and that an opioid-receptor-dependent inhibition of the Ehrlich tumor-induced hyperalgesia was being observed, mice were treated with naloxone $(1 \mathrm{mg} / \mathrm{kg}$, i.p.) $1 \mathrm{~h}$ before morphine $(10 \mathrm{mg} / \mathrm{kg})$ treatment, and after additional $45 \mathrm{~min}$, measurements of mechanical (Figure 6(d)) and thermal (Figure 6(e)) hyperalgesia were performed. Again, the Ehrlich tumorinduced $\left(10^{6}\right.$ cells) mechanical and thermal hyperalgesia were inhibited by morphine, and this inhibition was prevented by naloxone treatment. Furthermore, the Ehrlich tumor induced $\left(10^{7}\right.$ cells $)$ spontaneous flinches at the 8th day 


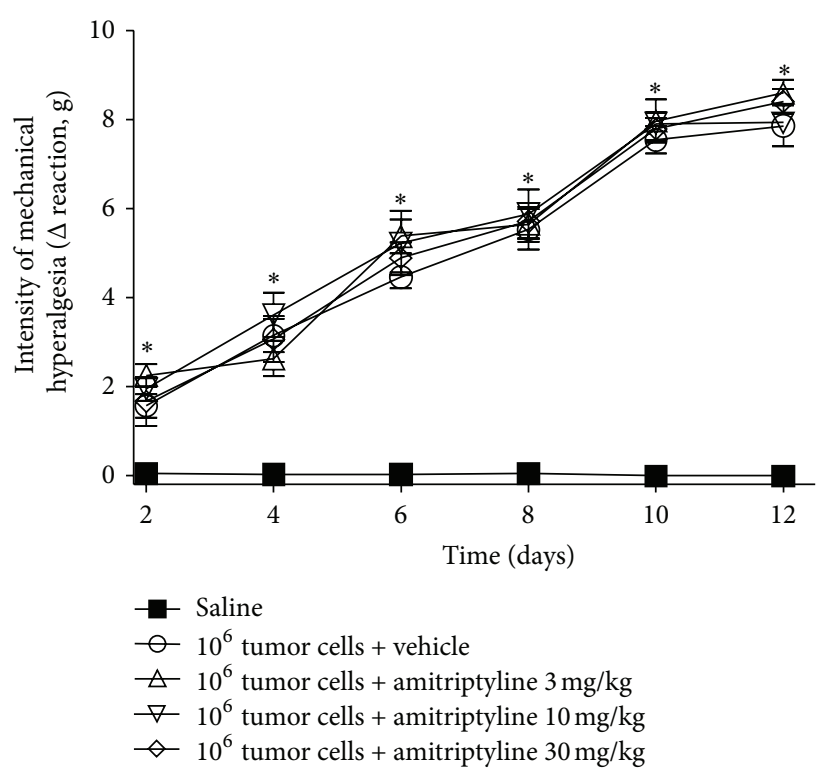

(a)

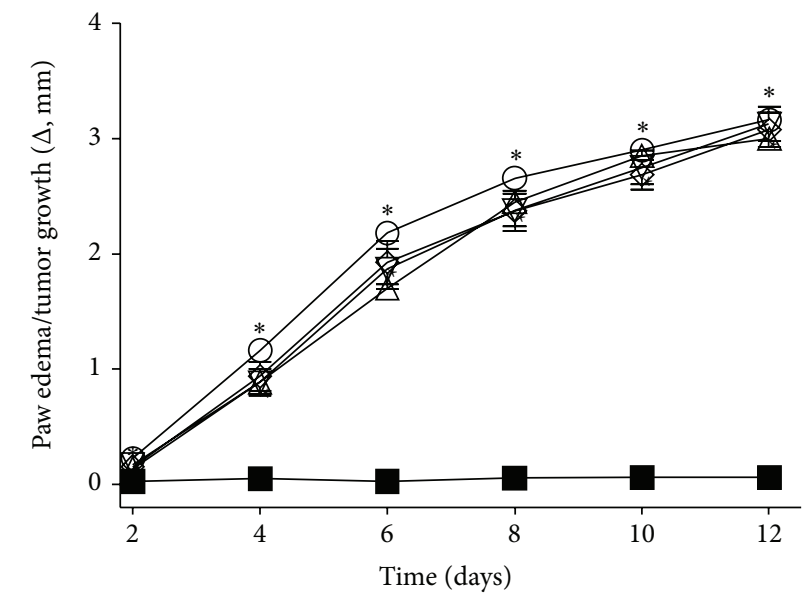

Saline

- $10^{6}$ tumor cells + vehicle

$\triangle 10^{6}$ tumor cells + amitriptyline $3 \mathrm{mg} / \mathrm{kg}$

$\nabla 10^{6}$ tumor cells + amitriptyline $10 \mathrm{mg} / \mathrm{kg}$

$\diamond 10^{6}$ tumor cells + amitriptyline $30 \mathrm{mg} / \mathrm{kg}$

(c)

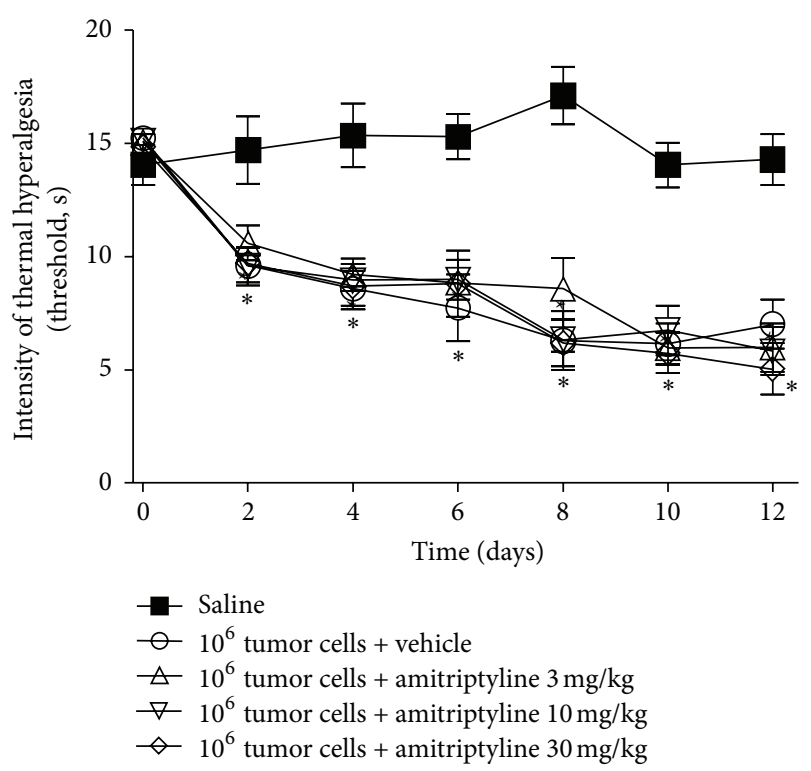

(b)

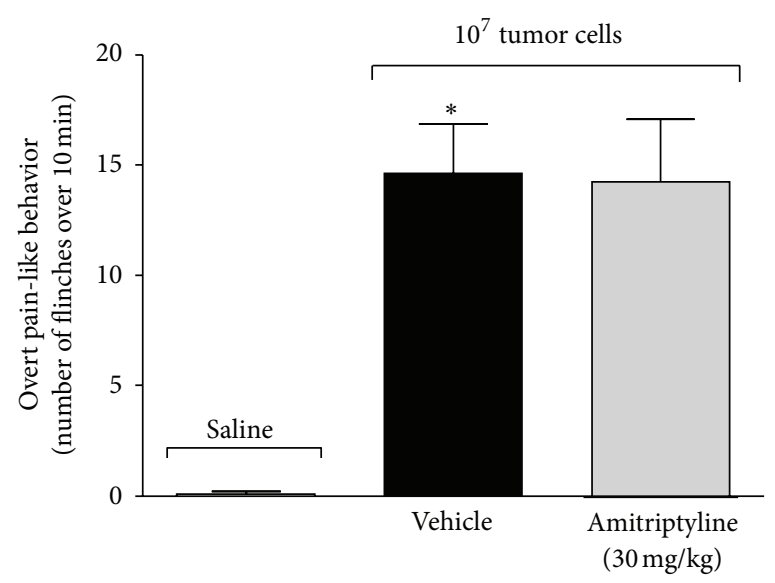

(d)

FIGURE 5: Effect of amitriptyline treatment on pain and paw edema/tumor growth induced by the Ehrlich tumor cells. Mice received the $1 \times$ $10^{6}$ Ehrlich tumor cells or saline, and they were treated with amitriptyline (3-30 mg/kg, p.o.) or water every day after subcutaneous injection of tumor cells. (a) The intensity of mechanical hyperalgesia, (b) thermal hyperalgesia, and (c) paw edema/tumor growth was evaluated $3 \mathrm{~h}$ after the treatment on days $2,4,6,8,10$, and 12 after injection of the cells. Mice received the $1 \times 10^{7}$ Ehrlich tumor cells or saline and were treated daily with amitriptyline $(30 \mathrm{mg} / \mathrm{kg}$, p.o.) or water and after 8 days; (d) the overt pain was assessed $3 \mathrm{~h}$ after the treatment; $n=6$, representative of two experiments. ${ }^{*} P<0.05$ compared with the saline.

of cancer development, which were also inhibited by morphine treatment $(10 \mathrm{mg} / \mathrm{kg})$, and the analgesic effect of morphine was prevented by naloxone treatment (Figure 6(f)). Therefore, the Ehrlich tumor induces mechanical and thermal hyperalgesia and overt pain-like behavior susceptible to opioid-receptor analgesia (Figure 6).

\section{Discussion}

Cancer pain directly affects the quality of life and survival of patients with cancer $[11,30]$. Cancer pain is characterized by the presence of hyperalgesia, allodynia, and/or spontaneous pain. Tactile allodynia and mechanical hyperalgesia 


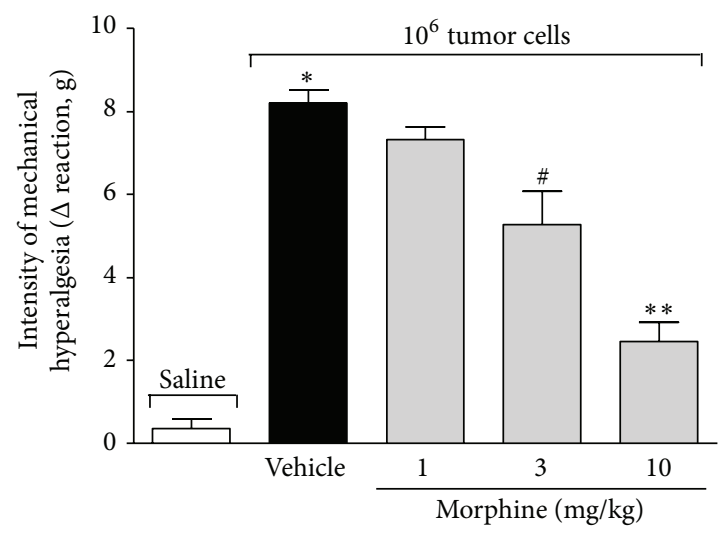

(a)

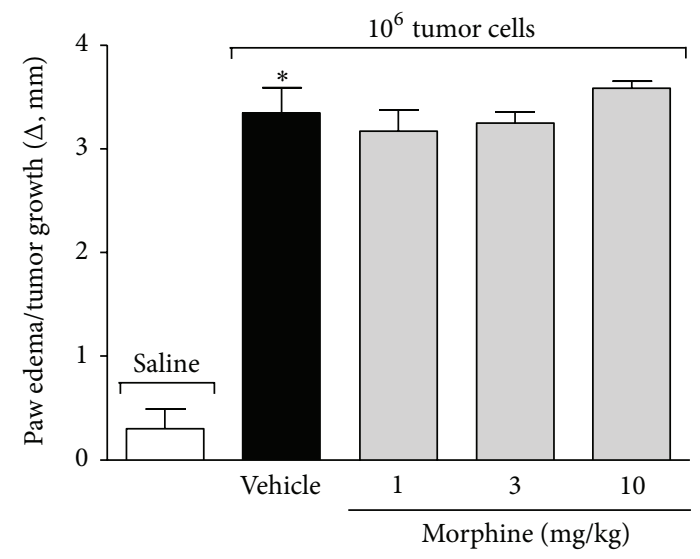

(c)

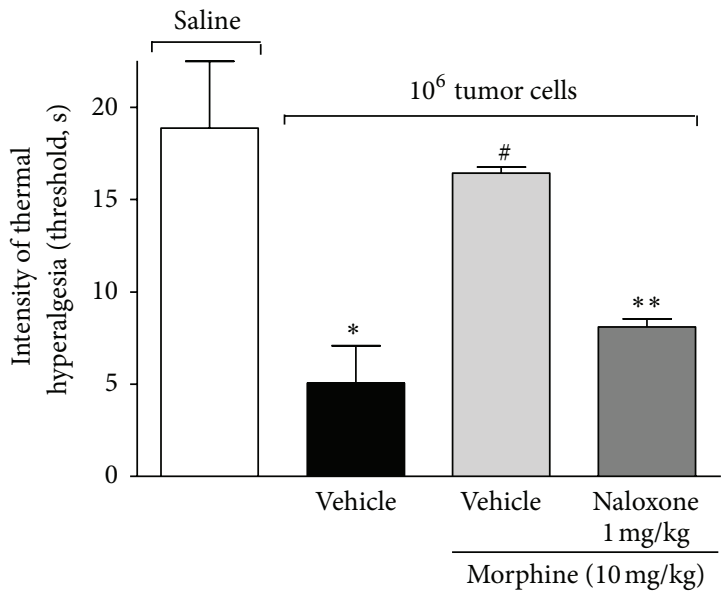

(e)

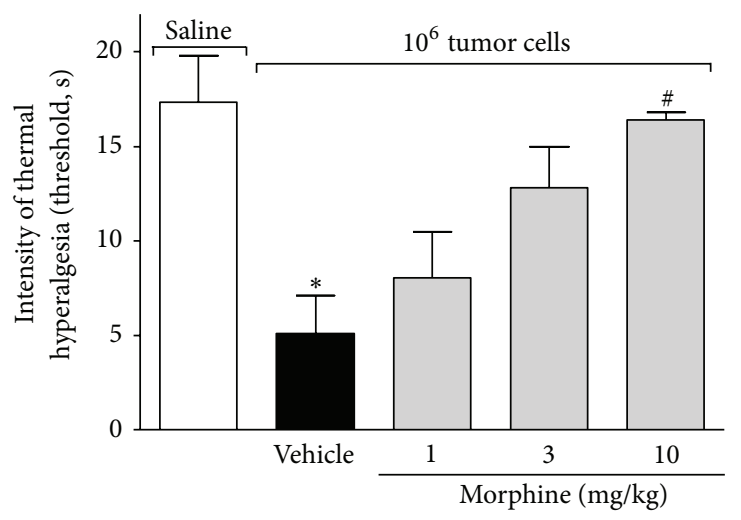

(b)

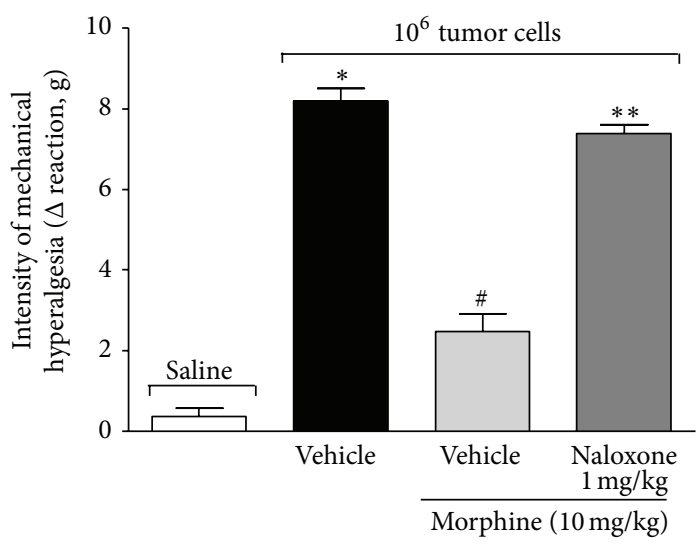

(d)

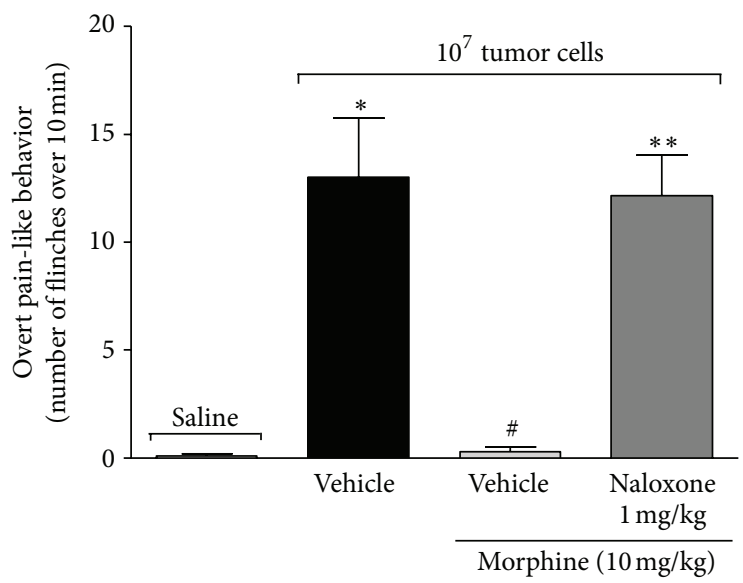

(f)

FIGURE 6: Effect of morphine treatment on pain and paw edema/tumor growth induced by the Ehrlich tumor cells. Mice that received the $1 \times 10^{6}$ Ehrlich tumor cells were treated with morphine $(1-10 \mathrm{mg} / \mathrm{Kg}$, i.p.) or saline on the 8th day after tumor cells injection. (a) The intensity of mechanical hyperalgesia, (b) thermal hyperalgesia, and (c) paw edema/tumor growth was evaluated 45 minutes after treatment with morphine. In another set, mice were treated with naloxone $(1 \mathrm{mg} / \mathrm{kg}$, i.p.) 1 hour before the treatment with morphine (10 mg/kg i.p.), and (d) 45 minutes after morphine treatment, the intensity of mechanical hyperalgesia and (e) thermal hyperalgesia was evaluated. Mice received the $1 \times 10^{7}$ Ehrlich tumor cells or saline, and after 8 days, they were treated with naloxone $(1 \mathrm{mg} / \mathrm{kg}$ i.p.) $1 \mathrm{~h}$ before treatment with morphine $(10 \mathrm{mg} / \mathrm{kg}$ i.p.), and (f) $45 \mathrm{~min}$ after the treatment with morphine, the overt pain was assessed; $n=6$, representative of two experiments. ${ }^{*} P<0.05$ vehicle group compared with the saline; ${ }^{\#} P<0.05$ compared with the tumor or compared with the treatment with naloxone plus morphine, and ${ }^{* *} P<0.05$ compared with the doses of 1 and $3 \mathrm{mg} / \mathrm{kg}$ morphine. 
are important features of cancer pain and decrease the life quality of patients. Considering the importance of pain in cancer, several experimental models, including neuropathic cancer pain [11], bone cancer pain $[12,31,32]$, and cancer pain induced by orthotopic tumor inoculation in mice $[10,33]$, have been developed and contributed to the characterization of the pathophysiology of cancer pain.

Several experimental studies have shown that marked nociceptive reactions induced by malignant tumor vary with animal species, tumor types, and localizations of the tumor [10-12, 33-36]. In the present study, we develop a model of pain characterized by mechanical and thermal hyperalgesia and spontaneous pain-like behavior, for example, flinching of the paw. The mechanical hyperalgesia and flinches were dependent on the number of the Ehrlich tumor cells injection and were progressive over time. The time- and dosedependent features of the present model argue in its favor as a good model to investigate the effect of novel analgesics and mechanisms involved in cancer pain regarding mechanical hyperalgesia and overt pain-like behavior. It is noteworthy that, in the case of thermal hyperalgesia, it was significant and increased over time, but there were no differences in the responses induced by different number of the Ehrlich tumor cells injected.

It is important to understand the mechanisms involved in the model used to investigate the action of novel drugs and to have a clear view of the possible mechanisms to be addressed. Nevertheless, as a first insight into the mechanisms involved in the Ehrlich tumor-induced nociception, it was determined its susceptibility to three classes of analgesics; nonsteroidal anti-inflammatory drug, tricyclic antidepressant, and opioid. The acute treatment with nonsteroidal anti-inflammatory drug, indomethacin, a cyclooxygenase inhibitor, did not affect the nociceptive responses and paw edema/tumor growth induced by the Ehrlich tumor. Indomethacin did not affect pain in a model of femur cancer pain induced by fibrosarcoma cells in mice [37]. On the other hand, in a model of bone cancer pain induced by injection of osteolytic murine sarcoma into the femur, the oral administration of indomethacin reduced pain behavior in mice [38]. These controversial data may be due to the different routes of administration that were used, the different doses of treatment, and mainly the different models of cancer pain.

Chronic treatment with amitriptyline, a tricyclic antidepressant inhibitor of reuptake of serotonin and norepinephrine, did not inhibit the nociception induced by the Ehrlich tumor cells. Others have shown that amitriptyline reduced only spontaneous pain behavior at sedative doses [37]. Tricyclic antidepressants have been extensively studied because there is evidence of their analgesic properties in several chronic diseases [37], and neuropathic pain [39]. However, the reuptake of serotonin and norepinephrine seems not to be related to the maintenance of cancer pain induced by the Ehrlich tumor.

The treatment with morphine dose dependently reduced the nociception induced by the Ehrlich tumor. Additionally, it was observed that the effect of morphine was receptor specific, because the opioid receptor antagonist naloxone reversed the effect of morphine. Despite the reduction of nociception promoted by morphine, there was no change in tumor growth, which indicates that morphine inhibited nociceptive responses rather than reduced nociception by decreasing tumor growth.

Despite all of the research performed in an attempt to inhibit cancer pain, it cannot be stated the exact mechanisms involved in the maintenance and chronicity of cancer pain. In fact, cancer patients still face inadequate analgesia. One major reason is that, despite some similarities, each model of cancer pain has its peculiar mechanisms similarly to each type of cancer in humans. Thus, it is conceivable that a great variety of cancer pain models are necessary to line up with varied human conditions. Bone cancer pain models are considered particularly interesting since during metastasis tumor cells may reach the bones. In the present study, there was bone cartilage destruction in the foci of tumor injected, indicating that there might be a bone pain component in this model. Nevertheless, models that evaluate the pain before metastasis are also important. To exemplify conditions in which cancer pain before metastasis is important, it is noteworthy to mention that a third of breast cancer patients will report pain in the lump spontaneously or upon examination [40]. The present model using the injection of cells of a murine mammary adenocarcinoma presents a condition resembling the preoperative breast cancer pain since there is spontaneous pain-like behavior in the paw and hyperalgesia upon stimulation of the lump (foci of tumor injection in the paw). Importantly, there is a significant relation between preoperative breast pain and phantom breast pain syndrome [41], and treatment of pain prior to mastectomy is an important clinical approach to reduce the incidence of phantom breast pain syndrome. Therefore, the present model might contribute as a model to study preoperative breast cancer pain mechanisms.

\section{Conclusion}

We have characterized a cancer pain model induced by subcutaneous injection of the Ehrlich tumor cells into the hindpaw of mice. This model is characterized by robust tumor growth and rapid development of mechanical and thermal hyperalgesia and overt pain-like behavior, rendering it as convenient to study the mechanisms of cancer pain and tumor growth and to test new treatments.

\section{Conflict of Interests}

The authors declare that they have no conflict of interests.

\section{Acknowledgments}

The authors appreciate the technical support of Jesus Vargas, Pedro Dionísio Filho, Talita P. Domiciano (received a SETI/Fundação Araucária and Parana State Government fellowship), and Miriam S. N. Hohmann for the English editing. This work was supported by grants from SETI/Fundação Araucária, Parana State Government, Fundo de Apoio ao Ensino Pesquisa e Extensão/Universidade Estadual de Londrina (FAEPE/UEL 01/2011 and 02/2011), Conselho Nacional 
de Desenvolvimento Científico e Tecnológico (CNPq), and Coordenadoria de Aperfeiçoamento de Pessoal de Nível Superior (CAPES), Brazil. W. A. Verri Jr. received a senior research fellowship from CNPq, and R. Cecchini, E. G. Moreira and R. Casagrande received senior research fellowship from SETI/Fundação Araucária and Parana State Government.

\section{References}

[1] P. E. Greenberg, S. A. Leong, H. G. Birnbaum, and R. L. Robinson, "The economic burden of depression with painful symptoms," Journal of Clinical Psychiatry, vol. 64, no. 7, pp. 1723, 2003.

[2] C. R. Green, S. K. Ndao-Brumblay, and T. Hart-Johnson, "Sleep problems in a racially diverse chronic pain population," Clinical Journal of Pain, vol. 25, no. 5, pp. 423-430, 2009.

[3] W. F. Stewart, J. A. Ricci, E. Chee, D. Morganstein, and R. Lipton, "Lost productive time and cost due to common pain conditions in the US workforce," Journal of the American Medical Association, vol. 290, no. 18, pp. 2443-2454, 2003.

[4] D. C. Turk, "Clinical effectiveness and cost-effectiveness of treatments for patients with chronic pain," Clinical Journal of Pain, vol. 18, no. 6, pp. 355-365, 2002.

[5] K. O. Anderson, T. R. Mendoza, V. Valero et al., "Minority cancer patients and their providers: pain management attitudes and practice," Cancer, vol. 88, no. 8, pp. 1929-1938, 2000.

[6] J. E. Nelson, D. E. Meier, E. J. Oei et al., "Self-reported symptom experience of critically ill cancer patients receiving intensive care," Critical Care Medicine, vol. 29, no. 2, pp. 277-282, 2001.

[7] A. Caraceni, "Evaluation and assessment of cancer pain and cancer pain treatment," Acta Anaesthesiologica Scandinavica, vol. 45, no. 9, pp. 1067-1075, 2001.

[8] C. R. Green, T. Hart-Johnson, and D. R. Loeffler, "Cancerrelated chronic pain," Cancer, vol. 117, no. 9, pp. 1994-2003, 2011.

[9] M. H. J. van den Beuken-van Everdingen, J. M. de Rijke, A. G. Kessels, H. C. Schouten, M. van Kleef, and J. Patijn, "Prevalence of pain in patients with cancer: a systematic review of the past 40 years," Annals of Oncology, vol. 18, no. 9, pp. 1437-1449, 2007.

[10] T. Sasamura, S. Nakamura, Y. Iida et al., "Morphine analgesia suppresses tumor growth and metastasis in a mouse model of cancer pain produced by orthotopic tumor inoculation," European Journal of Pharmacology, vol. 441, no. 3, pp. 185-191, 2002.

[11] M. Shimoyama, K. Tanaka, F. Hasue, and N. Shimoyama, "A mouse model of neuropathic cancer pain," Pain, vol. 99, no. 1-2, pp. 167-174, 2002.

[12] M. J. Schwei, P. Honore, S. D. Rogers et al., "Neurochemical and cellular reorganization of the spinal cord in a murine model of bone cancer pain," Journal of Neuroscience, vol. 19, no. 24, pp. 10886-10897, 1999.

[13] P. W. Wacnik, L. J. Eikmeier, T. R. Ruggles et al., "Functional interactions between tumor and peripheral nerve: morphology, algogen identification, and behavioral characterization of a new murine model of cancer pain," Journal of Neuroscience, vol. 21, no. 23, pp. 9355-9366, 2001.

[14] P. W. Mantyh, "Mechanisms of malignant bone pain," in Cancer Pain: From Molecules to Suffering, A. J. Paice, R. F. Bell, E. A. Kalso, and O. A. Soyannwo, Eds., chapter 3, pp. 45-62, IASP Press, Washington, DC, USA, 1st edition, 2010.
[15] M. Kress, "Cytokines and cancer pain," in Cancer Pain: From Molecules to Suffering, A. J. Paice, R. F. Bell, E. A. Kalso, and O. A. Soyannwo, Eds., chapter 4, pp. 63-84, IASP Press, Washington, DC, USA, 1st edition, 2010

[16] P. Ehrlich and H. Apolant, "Beobachtungen uber maligne mausetumoren," Berliner Klinische Wochenschrift, vol. 42, pp. 871874,1905

[17] H. Loewenthal and G. Jahn, "Übertragunsversuche mit carcinomatöser Mäuse-Ascitesflüssigkeit und ihr Verhalten gegen physikalische und chemische Einwirkungen," Zeitschrift für Krebsforschung, vol. 37, no. 1, pp. 439-447, 1932.

[18] H. Ahmed, B. P. Chatterjee, and A. K. Debnath, "Interaction and in vivo growth inhibition of Ehrlich ascites tumor cells by jacalin," Journal of Biosciences, vol. 13, no. 4, pp. 419-424, 1988.

[19] S. Kametani, T. Oikawa, A. Kojima-Yuasa et al., "Mechanism of growth inhibitory effect of cape aloe extract in Ehrlich ascites tumor cells," Journal of Nutritional Science and Vitaminology, vol. 53, no. 6, pp. 540-546, 2007.

[20] E. Balamurugan, B. V. Reddy, and V. P. Menon, "Antitumor and antioxidant role of Chrysaora quinquecirrha (sea nettle) nematocyst venom peptide against ehrlich ascites carcinoma in Swiss Albino mice," Molecular and Cellular Biochemistry, vol. 338, no. 1-2, pp. 69-76, 2009.

[21] A. Kumar, S. S. D’Souza, S. R. Mysore Nagaraj, S. L. Gaonkar, B. P. Salimath, and K. M. L. Rai, "Antiangiogenic and antiproliferative effects of substituted-1,3,4-oxadiazole derivatives is mediated by down regulation of VEGF and inhibition of translocation of HIF-1 $\alpha$ in Ehrlich ascites tumor cells," Cancer Chemotherapy and Pharmacology, vol. 64, no. 6, pp. 1221-1233, 2009.

[22] J. Fastaia and A. E. Dumont, "Pathogenesis of ascites in mice with peritoneal carcinomatosis," Journal of the National Cancer Institute, vol. 56, no. 3, pp. 547-550, 1976.

[23] F. Hartveit, "The immediate cause of death in mice with Ehrlich's ascites carcinoma," Acta Pathologica et Microbiologica Scandinavica, vol. 65, no. 3, pp. 359-365, 1965.

[24] K. D. Mayer, "The pathogenicity of the Ehrlich ascites tumour," British Journal of Experimental Pathology, vol. 47, no. 5, pp. 537544, 1966.

[25] J. Vieira, P. Matsuzaki, M. K. Nagamine et al., "Inhibition of ascitic Ehrlich tumor cell growth by intraperitoneal injection of Pfaffia paniculata (Brazilian ginseng) butanolic residue," Brazilian Archives of Biology and Technology, vol. 53, no. 3, pp. 609-613, 2010.

[26] X. Zhu, H. Wu, J. Xia, M. Zhao, and Z. Xianyu, “The relationship between ${ }^{99 \mathrm{~m}} \mathrm{Tc}$-MIBI uptakes and tumor cell death/proliferation state under irradiation," Cancer Letters, vol. 182, no. 2, pp. 217-222, 2002.

[27] P. Brigatte, S. C. Sampaio, V. P. Gutierrez et al., "Walker 256 tumor-bearing rats as a model to study cancer pain," Journal of Pain, vol. 8, no. 5, pp. 412-421, 2007.

[28] T. M. Cunha, W. A. Verri Jr., G. G. Vivancos et al., "An electronic pressure-meter nociception paw test for mice," Brazilian Journal of Medical and Biological Research, vol. 37, no. 3, pp. 401-407, 2004.

[29] D. A. R. Valério, T. M. Cunha, N. S. Arakawa et al., "Antiinflammatory and analgesic effects of the sesquiterpene lactone budlein $\mathrm{A}$ in mice: inhibition of cytokine productiondependent mechanism," European Journal of Pharmacology, vol. 562, no. 1-2, pp. 155-163, 2007.

[30] S. J. Medhurst, K. Walker, M. Bowes et al., "A rat model of bone cancer pain," Pain, vol. 96, no. 1-2, pp. 129-140, 2002. 
[31] D. R. Clohisy, C. M. Ogilvie, and M. L. R. Ramnaraine, "Tumor osteolysis in osteopetrotic mice," Journal of Orthopaedic Research, vol. 13, no. 6, pp. 892-897, 1995.

[32] L. Menendéz, L. Juárez, V. García, A. Hidalgo, and A. Baamond, "Involvement of nitric oxide in the inhibition of bone cancerinduced hyperalgesia thought the activation of peripheral opioid receptors in mice," Neuropharmacology, vol. 53, no. 1, pp. 71-80, 2007.

[33] Y. Kuraishi, Y. Iida, H. Zhang et al., "Suppression by gabapentin of pain-related mechano-responses in mice given orthotopic tumor inoculation," Biological and Pharmaceutical Bulletin, vol. 26, no. 4, pp. 550-552, 2003.

[34] N. M. Luger, P. Honore, M. A. C. Sabino et al., "Osteoprotegerin diminishes advanced bone cancer pain," Cancer Research, vol. 61, no. 10, pp. 4038-4047, 2001.

[35] R. K. Portenoy and G. Frager, "Pain management: pharmacological approaches," Cancer Treatment and Research, vol. 100, pp. $1-29,1999$.

[36] M. Shimoyama, H. Tatsuoka, S. Ohtori, K. Tanaka, and N. Shimoyama, "Change of dorsal horn neurochemistry in a mouse model of neuropathic cancer pain," Pain, vol. 114, no. 1-2, pp. 221-230, 2005.

[37] M. E. Mouedden and T. F. Meert, "Pharmacological evaluation of opioid and non-opioid analgesics in a murine bone cancer model of pain," Pharmacology Biochemistry and Behavior, vol. 86, no. 3, pp. 458-467, 2007.

[38] O. Saito, T. Aoe, and T. Yamamoto, "Analgesic effects of nonsteroidal antiinflammatory drugs, acetaminophen, and morphine in a mouse model of bone cancer pain," Journal of Anesthesia, vol. 19, no. 3, pp. 218-224, 2005.

[39] K. Vissers, V. Hoffmann, F. Geenen, R. Biermans, and T. Meert, "Is the second phase of the formalin test useful to predict activity in chronic constriction injury models? A pharmacological comparison in different species," Journal of World Institute of Pain, vol. 3, no. 4, pp. 298-309, 2003.

[40] W. G. Harris, E. A. Benson, D. Cartwright et al., "Symptoms and signs of operable breast cancer," The Journal of the Royal College of General Practitioners, vol. 33, pp. 473-476, 1983.

[41] K. Kroner, B. Krebs, J. Skov, and H. S. Jorgensen, "Immediate and long-term phantom breast syndrome after mastectomy: incidence, clinical characteristics and relationship to premastectomy breast pain," Pain, vol. 36, no. 3, pp. 327-334, 1989. 


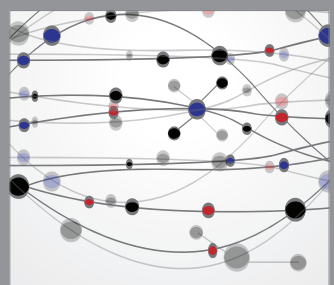

The Scientific World Journal
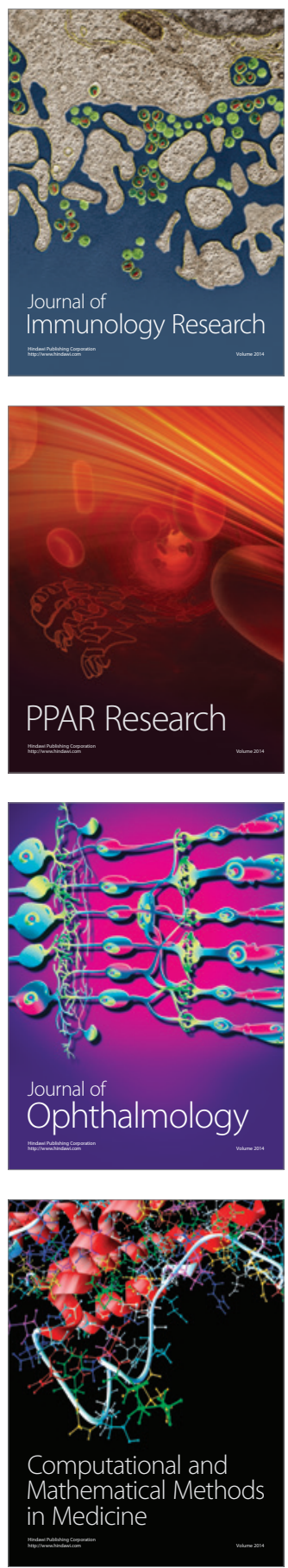

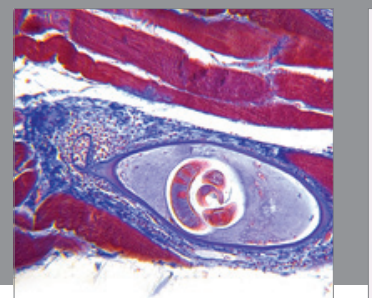

Gastroenterology

Research and Practice
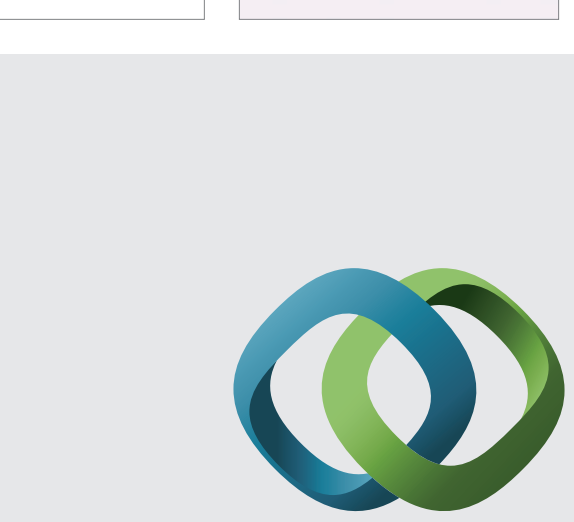

\section{Hindawi}

Submit your manuscripts at

http://www.hindawi.com
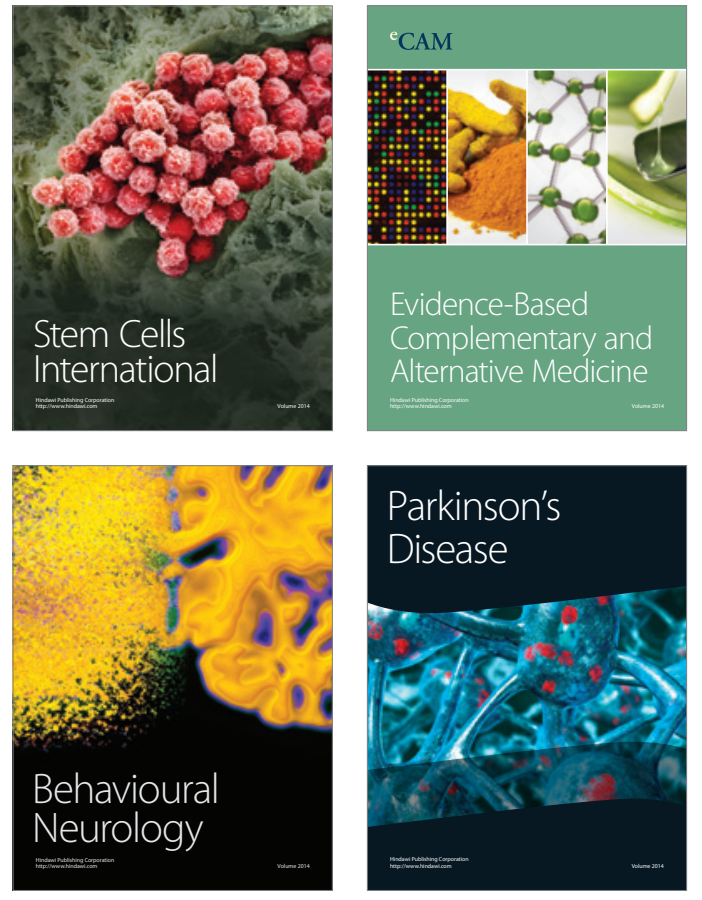
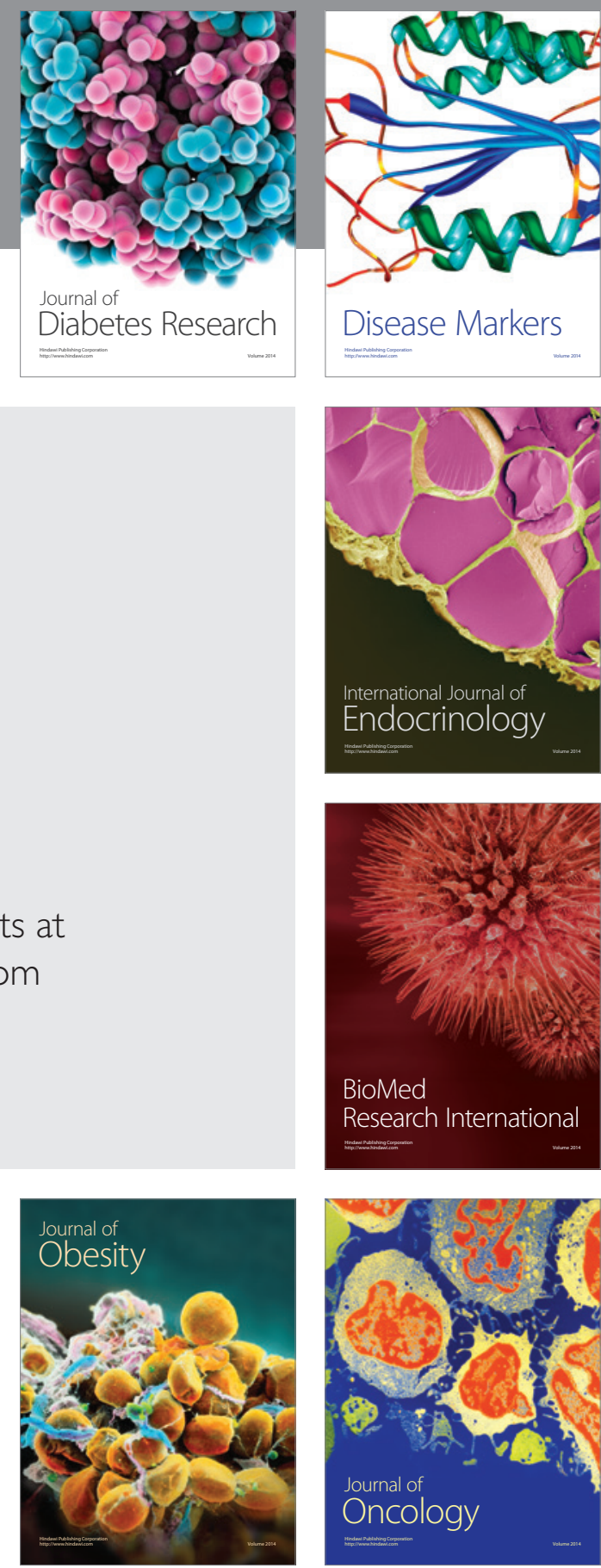

Disease Markers
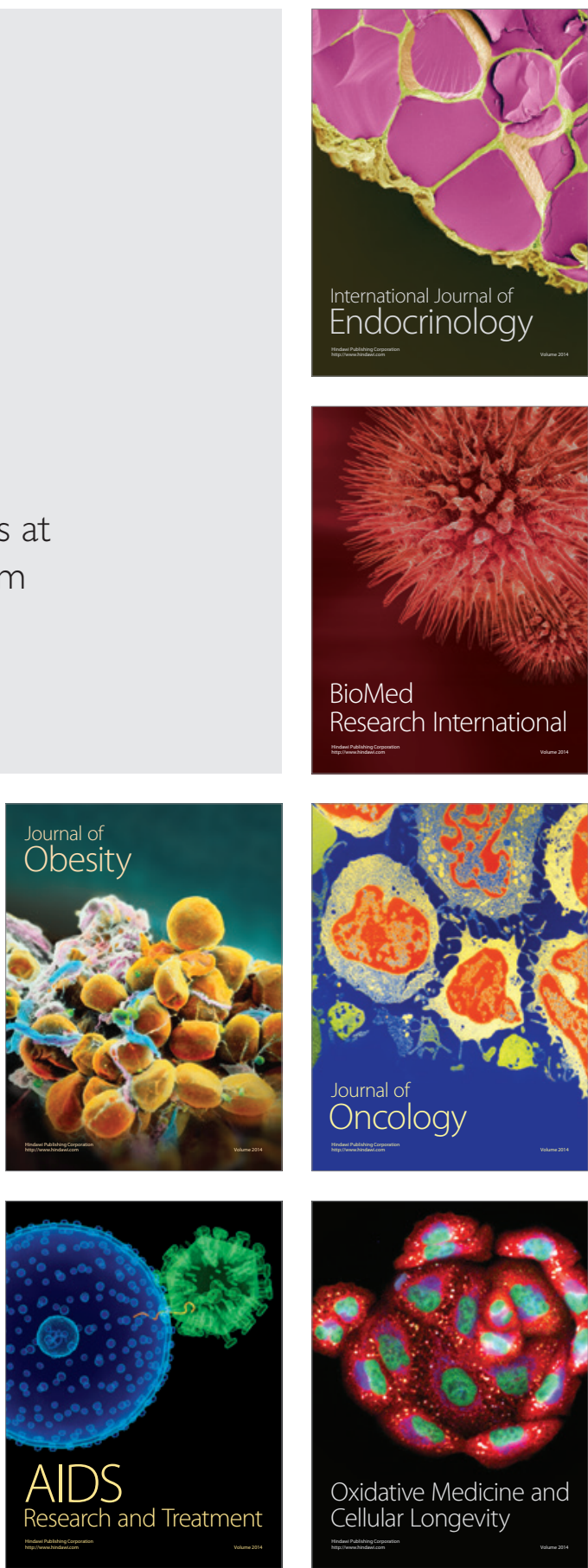